\title{
Synthetic Peptide Combinatorial Libraries: A Method for the Identification of Bioactive Peptides Against Phytopathogenic Fungi
}

\author{
Jerry D. Reed, ${ }^{1}$ David L. Edwards, ${ }^{2}$ and Carlos F. Gonzalez ${ }^{1}$ \\ ${ }^{1}$ Department of Plant Pathology and Microbiology, Texas A\&M University, College Station 77843-2132 \\ U.S.A.; ${ }^{2}$ Ceres Technologies, Inc., San Antonio, TX 78230 U.S.A. \\ Received 20 December 1996. Accepted 18 March 1997.
}

\begin{abstract}
Synthetic combinatorial libraries were evaluated with an iterative process to identify a hexapeptide with broadspectrum activity against selected phytopathogenic fungi. A D-amino acid hexapeptide (FRLKFH) and pentapeptide (FRLHF) exhibited activity against Fusarium oxysporum f. sp. lycopersici, Rhizoctonia solani (anastomosis group 1), Ceratocystis fagacearum, and Pythium ultimum. The peptides showed no hemolytic or mutagenic activity. Fluorescent microscopy studies with a membrane impermeant dye indicated that fungal cytoplasmic membranes were compromised rapidly and that the nuclear membrane was also affected.
\end{abstract}

Additional keywords: antifungal, synthetic peptide.

Plants and animals have various defense mechanisms that allow them to resist infection by pathogenic fungi and bacteria. Among such defenses are an array of naturally occurring, antimicrobial peptides produced by various organisms that elicit a potent antimicrobial response (Zasloff 1987; Bowman et al. 1991; Hansen 1993). Antimicrobial peptides constitute an important defense mechanism. Recent studies have established the composition and structure of naturally occurring peptides and have examined details of their modes of action through the use of synthetic peptides (Bessalle et al. 1990; Chikindas et al. 1993; Merrifield et al. 1994; Marcos et al. 1995). For example, Merrifield et al. (1994) employed synthetic peptide chemistry to establish the primary sequences of the cecropins and determined the steps involved in their biosynthesis. From this information, they were able to develop cecropin analogues that were more active and stable and that had a broader spectrum of activity. Marcos et al. (1995) used synthetic peptide chemistry to identify specific synthetic peptide inhibitors of plant viral infection by tobacco mosaic virus (TMV). They used synthetic peptide chemistry to develop analogues of mellitin (26-amino acid residues) that inhibited infection by TMV. Another novel way to utilize synthetic peptide chemistry has been demonstrated by Hightower et al. (1994). They transformed a synthetic cecropin gene into tobacco plants in order to produce the cecropin peptide in planta and give resistance to the leaf pathogen Pseudomonas syringae pv. tabaci. Ultimately, the peptide was produced in levels

Corresponding author: C. F. Gonzalez; E-mail: cfg2536@acs.tamu.edu too low to provide significant disease suppression. However, the strategy of protecting plants by expression of peptide antibiotics holds much promise.

Designed synthetic antimicrobial peptides are becoming more important as investigators search for new and innovative approaches to control disease. The use of combinatorial libraries to identify synthetic peptides that exhibit antimicrobial activity offers an efficient methodology to identify novel peptides. Blondelle and Houghten (1996) have described three categories of peptide libraries: molecular biology techniques, in which peptides are presented on the surface of filamentousphage particles or plasmids; synthetic chemistry techniques for the generation of solid-support-bound compounds; and chemical synthesis of mixtures of soluble, free compounds. Houghten et al. (1992) have demonstrated the use of synthetic peptide combinatorial libraries (SPCLs) to identify bioactive peptides. Several studies (Houghten et al. 1993; Blondelle et al. 1994; Blondelle et al. 1995) have used the iterative process to screen SPCLs to identify peptide sequences having antimicrobial activity against pathogenic bacteria and yeast.

In the present study, we focused on a systematic evaluation of SPCLs to identify a bioactive pentapeptide (PPD1) and hexapeptide (66-10) with activity against filamentous phytopathogenic fungi. The defined peptides were compared for bioactivity to known antifungal compounds and tested for mutagenicity and hemolytic activity, and the potential target site of peptide D-FRLKFH was examined.

\section{RESULTS}

Determination of optimum inoculum concentration and incubation conditions for bioassay.

Growth studies were performed for the four fungal pathogens in order to determine the proper conditions for the bioassay. An initial inoculum concentration of $5 \times 10^{3}$ fungal spores, microconidia, or mycelial fragments per $\mathrm{ml}$ under static conditions showed balanced growth and less variability in optical density readings made over a 72 -h period for $F$. oxysporum $\mathrm{f}$. sp. lycopersici (microconidia), $R$. solani (mycelial fragments), and $P$. ultimum (oospores). Higher inoculum concentrations and/or shaking conditions resulted in more variability in the optical density readings (recorded every $24 \mathrm{~h}$ ). The maximum optical density for each of the respective fungi was $0.950,0.270$, and 0.400 over the 72 -h period. An inocu- 
lum concentration of $5 \times 10^{4}$ spores per $\mathrm{ml}$ and static conditions were optimal for $C$. fagacearum (spores) based on optical density readings for $96 \mathrm{~h}$ (0.250 maximum). In addition to a determination of the proper inoculum concentration and incubation conditions for the respective fungal pathogens, a correlation was made of the optical density readings with the mycelial dry weights. Optical density versus dry weight plots showed a linear relationship for each of the fungal pathogens (data not shown).

\section{Development of a defined antimicrobial hexapeptide.}

To identify a hexapeptide with broad-spectrum activity, an iterative process was used (Fig. 1). The 400 D-amino acid peptide mixtures, designated the 26-series, were screened against $F$. oxysporum f. sp. lycopersici, $R$. solani, $C$. fagacearum, and P. ultimum. Peptide mixture FRXXXX (26-51) was chosen to construct the 36-series. This mixture showed $\mathrm{IC}_{50} \mathrm{~S}$ of $875,557,46$, and $492 \mu \mathrm{g} / \mathrm{ml}$ for $F$. oxysporum f. sp. $l y$ copersici, $R$. solani, $C$. fagacearum, and $P$. ultimum, respectively, with corresponding MICs of 2,030, 1083, 79, and 873 $\mu \mathrm{g} / \mathrm{ml}$, respectively. Screening of the 36 -series showed peptide

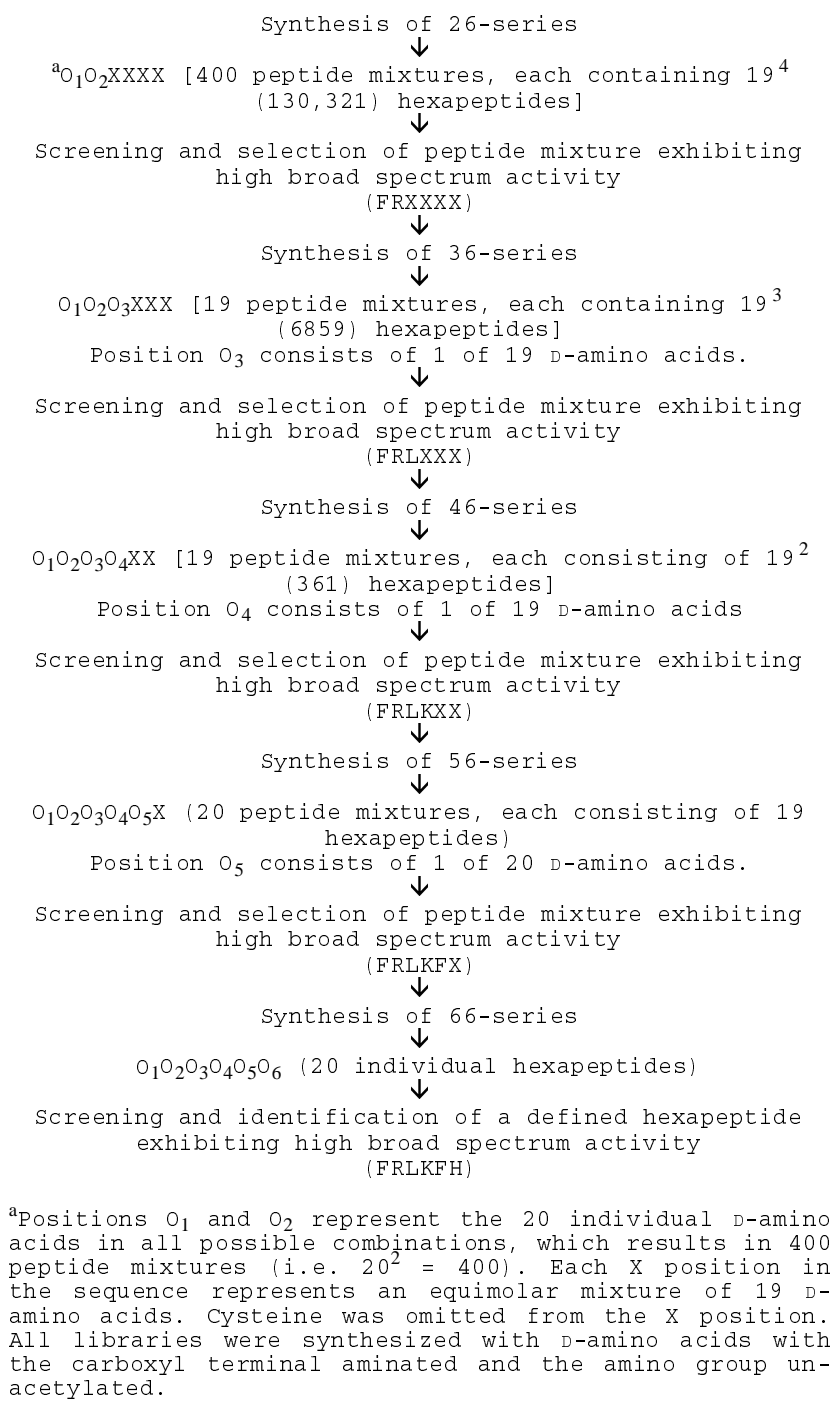

${ }^{a}$ Positions $O_{1}$ and $O_{2}$ represent the 20 individual $D$-amino acids in all possible combinations, which results in 400 peptide mixtures (i.e $\left.20^{2}-400\right)$ Tach $x$ position in peptide mixtures (i.e. $20=400$ ). Each $x$ position in amino acids. Cysteine was omitted from the $x$ position. All libraries were synthesized with D-amino acids with the carboxyl terminal aminated and the amino group unacetylated.

Fig. 1. Strategy used to identify hexapeptide 66-10. mixtures FRLXXX (36-18) and FRIXXX (36-12) to have broad-spectrum activity for the target fungi. The 36-18 mixture showed MICs of $614 \pm 6,134 \pm 12,68 \pm 9$, and $325 \pm 3$ $\mu \mathrm{g} / \mathrm{ml}$ for $F$. oxysporum f. sp. lycopersici, $R$. solani, $C$. fagacearum, and P. ultimum, respectively (Tables 1 to 4 , respectively). With the FRL sequence in positions $\mathrm{O}_{1}, \mathrm{O}_{2}$, and $\mathrm{O}_{3}$ for the 46-series, peptide mixture FRLKXX (46-17) was found to have the best activity against the target fungi. This mixture showed MICs of $337 \pm 8,28 \pm 5,35 \pm 3$, and $81 \pm 1$ $\mu \mathrm{g} / \mathrm{ml}$ for the respective fungal pathogens (Tables 1 to 4 , respectively). This information was used to develop the 56series designated $\mathrm{FRLKO}_{5} \mathrm{X}$, in which position $\mathrm{O}_{5}$ consisted of one of 20 D-amino acids. The peptide mixture FRLKFX (56-3) exhibited the desired activity and its sequence was chosen to construct the 20 defined hexapeptides designated the 66-series. The 56-3 peptide mixture showed MICs of $40 \pm 1$, $27 \pm 2,10 \pm 0$, and $41 \pm 1 \mu \mathrm{g} / \mathrm{ml}$ for the respective pathogens (Tables 1 to 4, respectively). After screening of the 66-series, hexapeptide FRLKFH (66-10) was chosen as the defined hexapeptide to undergo further investigation. Hexapeptide FRLKFH had MICs of $19 \pm 1,20 \pm 3,5 \pm 0$, and $36 \pm 7 \mu \mathrm{g} / \mathrm{ml}$ for $F$. oxysporum f. sp. lycopersici, $R$. solani, C. fagacearum, and $P$. ultimum, respectively (Tables 1 to 4 , respectively). With the iterative process, it was possible to obtain a 107-fold increase in activity, compared with FRXXXX (26-51), against F. oxysporum f. sp. lycopersici, a 54-fold increase against $R$. solani (AG-1), a 16-fold increase against $C$. fagacearum, and a 24-fold increase against $P$. ultimum. Testing of 66-10 against Ophiostoma ulmi and $R$. solani (AG-4) showed MICs of 16.5 \pm 0.3 and $58 \pm 5 \mu \mathrm{g} / \mathrm{ml}$, respectively. In addition to the development of hexapeptide 66-10, a pentapeptide with the sequence FRLHF was developed during our studies. This peptide exhibited MICs of $66 \pm 2,66 \pm 2,14 \pm 3$, and $55 \pm 12$ $\mu \mathrm{g} / \mathrm{ml}$ for $F$. oxysporum f. sp. lycopersici, $R$. solani (AG-1), $C$. fagacearum, and $P$. ultimum, respectively.

\section{Comparison of defined peptides to antifungal agents.}

The defined pentapeptide (PPD1) and hexapeptide (66-10) were compared with MBC, cycloheximide, and nystatin for antifungal activity. For comparison purposes the MIC of each compound was determined with the target fungi (Table 5). Of the commercial antifungals, MBC and cycloheximide had the greatest activity against the fungal pathogens. $C$. fagacearum was the most sensitive to all the antifungal agents tested. $P$. ultimum was sensitive to cycloheximide but lacked sensitivity to $\mathrm{MBC}$ or nystatin. Against $F$. oxysporum f. sp. lycopersici, 66-10 exhibited higher activity than did cycloheximide. However, 66-10 was almost 10-fold and fourfold less active than MBC and nystatin, respectively. Hexapeptide 66-10 exhibited about 10 -fold less activity than $\mathrm{MBC}$ and nystatin, and was 29-fold less active than cycloheximide against $R$. solani (AG1). When compared with MBC and nystatin, 66-10 was about fivefold less active against $C$. fagacearum. Against $P$. ultimum, 66-10 was sixfold less active than cycloheximide. Overall, 66-10 was approximately threefold more active than pentapeptide PPD1.

\section{Determination of potential target site of hexapeptide 66-10.}

Fluorescent microscopy was used to determine the potential target site of hexapeptide 66-10. Two fluorescent dyes, Sytox 
Green and fluorescent brightener 28, were used in the staining procedures. Figures $2 \mathrm{~A}$ and $3 \mathrm{~A}$ show ethanol-treated $C$. $f a$ gacearum spores and $F$. oxysporum f. sp. lycopersici microconidia, respectively, in the presence of Sytox. Both structures show a defined, intact nucleus where the dye has entered the spore and complexed with the nucleic acids. Figures $2 \mathrm{~B}$ and 3B show $C$. fagacearum spores and F. oxysporum f. sp. lycopersici microconidia, respectively, observed immediately after treatment with a mixture of Sytox and hexapeptide 6610. The photographs show that the impermeant dye has en-

Table 1. Minimum inhibitory concentrations (MICs) $(\mu \mathrm{g} / \mathrm{ml})$ of the peptide mixture series constructed to obtain a defined antifungal hexapeptide against Fusarium oxysporum f. sp. lycopersici

\begin{tabular}{|c|c|c|c|c|c|c|c|}
\hline \multicolumn{2}{|c|}{ 36-series } & \multicolumn{2}{|c|}{ 46-series } & \multicolumn{2}{|c|}{ 56-series } & \multicolumn{2}{|c|}{ 66-series } \\
\hline Peptide $^{a}$ & MIC & Peptide & MIC & Peptide & MIC & Peptide & MIC \\
\hline FRQXXX & $>2,500$ & FRLQXX & 2,435 & FRLKQX & $>625$ & FRLKFQ & $40 \pm 0$ \\
\hline FRSXXX & $>2,500$ & FRLSXX & $1,889 \pm 20$ & FRLKSX & $>625$ & FRLKFS & $39 \pm 2$ \\
\hline FRFXXX & $618 \pm 10^{\mathrm{b}}$ & FRLFXX & $584 \pm 12$ & $\overline{F R} \overline{L K} \bar{F} \bar{X}$ & $40 \pm \overline{1}$ & FRLKFF & $240 \pm 4$ \\
\hline FRAXXX & $>2,500$ & FRLAXX & $2,391 \pm 19$ & $\overline{F R} \overline{L K A} \bar{X}$ & $>6 \overline{25}$ & FRLKFA & $77 \pm 3$ \\
\hline FRNXXX & $>2,500$ & FRLNXX & 2375 & FRLKNX & $>625$ & FRLKFN & $124 \pm \pm 7$ \\
\hline FRWXXX & $1,807 \pm 16$ & FRLWXX & $>2,500$ & FRLKWX & $70 \pm 2$ & FRLKFW & $38 \pm 2$ \\
\hline FRVXXX & 534 & FRLVXX & 611 & FRLKVX & $62 \pm 2$ & FRLKFV & $39 \pm 1$ \\
\hline FRMXXX & $1,164 \pm 44$ & FRLMXX & 1,159 & FRLKMX & $80 \pm 2$ & FRLKFM & $76 \pm 2$ \\
\hline FRPXXX & $>2,500$ & FRLPXX & $>2,500$ & FRLKPX & $>625$ & FRLKFP & $532 \pm 14$ \\
\hline FRHXXX & $>2,500$ & FRLHXX & $308 \pm 4$ & FRLKHX & $>625$ & $\overline{\mathrm{FR}} \overline{\mathrm{LK}} \overline{\mathrm{F}} \overline{\mathrm{H}}$ & $-\overline{19} \pm 1$ \\
\hline FRRXXX & $>2,500$ & FRLRXX & $1,046 \pm 16$ & FRLKRX & $>625$ & $\overline{\mathrm{FR}} \overline{\mathrm{LK}} \overline{\mathrm{K}} \overline{\mathrm{F}}$ & $32 \pm 1$ \\
\hline FRIXXX & $318 \pm 0$ & FRLIXX & $641 \pm 10$ & FRLKIX & $42 \pm 1$ & FRLKFI & $133 \pm 11$ \\
\hline FRDXXX & $>2,500$ & FRLDXX & $>2,500$ & FRLKDX & $>625$ & FRLKFD & $627 \pm 10$ \\
\hline FRCXXX & $* \mathrm{c}$ & FRLCXX & $*$ & FRLKCX & $424 \pm 4$ & FRLKFC & $62 \pm 1$ \\
\hline FRGXXX & $>2,500$ & FRLGXX & $>2,500$ & FRLKGX & $>625$ & FRLKFG & $152 \pm 5$ \\
\hline FRTXXX & $>2,500$ & FRLTXX & $1,057 \pm 1$ & FRLKTX & $>625$ & FRLKFT & $39 \pm 1$ \\
\hline FRKXXX & $>2,500$ & $\overline{F R} \overline{L K X} \bar{X}$ & $3 \overline{37} \pm 8$ & FRLKKX & $>625$ & FRLKFK & $21 \pm 1$ \\
\hline FRLXXX & $614 \pm 6^{\mathrm{d}}$ & $\overline{\mathrm{FR}} \overline{\mathrm{LL}} \overline{\mathrm{X}} \overline{\mathrm{X}}$ & $631 \pm 12$ & FRLKLX & $40 \pm 0$ & FRLKFL & $72 \pm 1$ \\
\hline FRE $\bar{X} \overline{X X}$ & $>2, \overline{500}$ & FRLEXX & $>2,500$ & FRLKEX & $>625$ & FRLKFE & $157 \pm 1$ \\
\hline FRYXXX & $>2,500$ & FRLYXX & 2,003 & FRLKYX & $160 \pm 5$ & FRLKFY & $32 \pm 1$ \\
\hline
\end{tabular}

all peptide mixtures contain D-amino acids with the carboxyl terminal aminated and the amino group unacetylated.

${ }^{b}( \pm)$ indicates the average of three replicate evaluations.

${ }^{\mathrm{C}}$ Asterisk indicates that these mixtures were not synthesized.

${ }^{\mathrm{d}}$ Boxed peptide mixture from each series was chosen to construct the suceeding series. Boxed peptide mixture of the 66-series is the selected hexapeptide 66-10.

Table 2. Minimum inhibitory concentrations (MICs) $(\mu \mathrm{g} / \mathrm{ml})$ of the peptide mixture series constructed to obtain a defined antifungal hexapeptide against Rhizoctonia solani (AG-1)

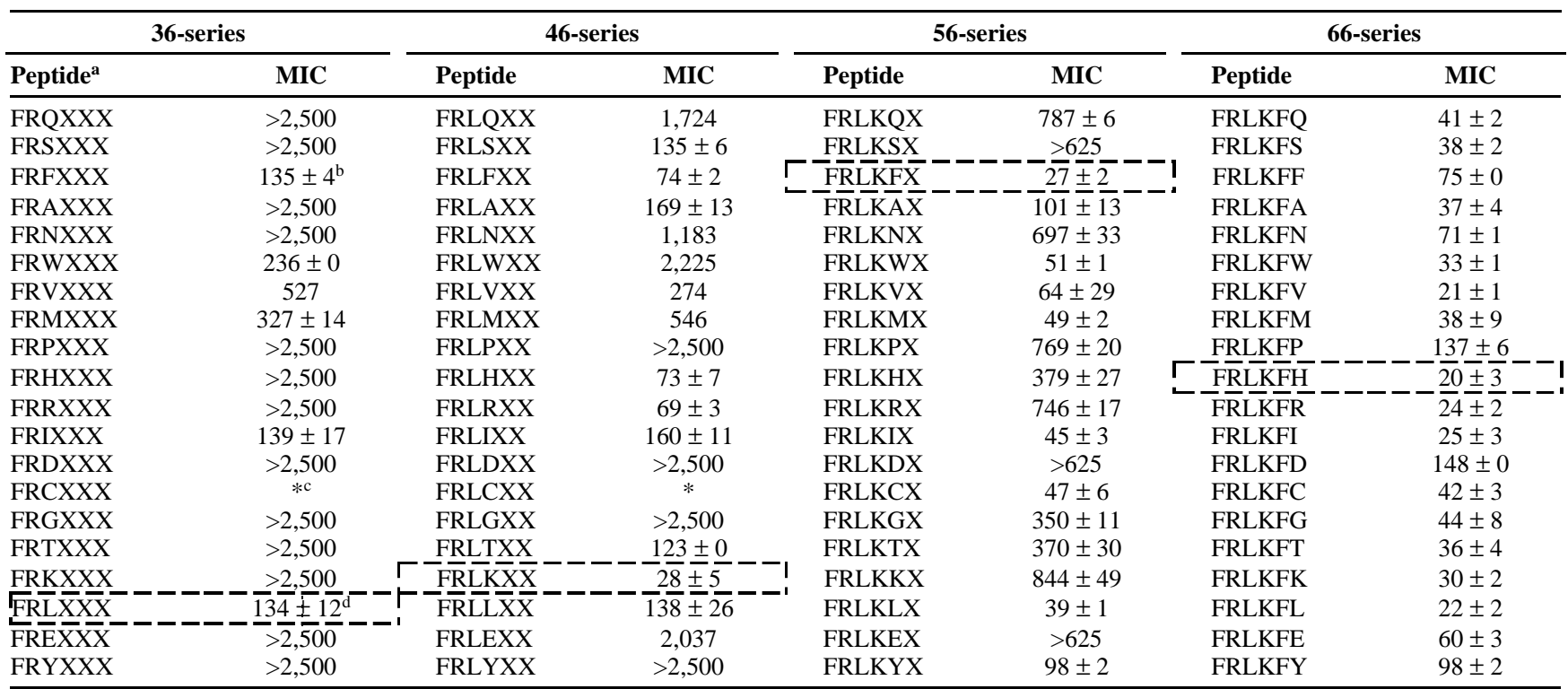

\footnotetext{
${ }^{a}$ All peptide mixtures contain D-amino acids with the carboxyl terminal aminated

and the amino group unacetylated.

$\mathrm{b}( \pm)$ indicates the average of three replicate evaluations.

$\mathrm{C}$ Asterisk indicates that these mixtures were not synthesized.

${ }^{\mathrm{d}}$ Boxed peptide mixture from each series was chosen to construct the suceeding series. Boxed peptide mixture of the 66-series is the selected hexapeptide 66-10.
} 
tered the peptide-treated spore and that the fungal structures have lost the defined nucleus and exhibit confluent staining. In companion experiments it was determined that cellular membranes were compromised and the nuclear membranes were also disrupted if the fungal structures were first incubated with
66-10 for $30 \mathrm{~min}$ and then stained (data not shown) or if the structures were incubated in the presence of a mixture of 6610 and Sytox (Figs. 2B and 3B). Fungal structures were also treated with ethanol, washed, incubated with the peptide for $30 \mathrm{~min}$, and then stained with Sytox without incubation, or

Table 3. Minimum inhibitory concentrations (MICs) $(\mu \mathrm{g} / \mathrm{ml})$ of the peptide mixture series constructed to obtain a defined antifungal hexapeptide against Ceratocystis fagacearum

\begin{tabular}{|c|c|c|c|c|c|c|c|}
\hline \multicolumn{2}{|c|}{ 36-series } & \multicolumn{2}{|c|}{ 46-series } & \multicolumn{2}{|c|}{ 56-series } & \multicolumn{2}{|c|}{ 66-series } \\
\hline Peptide $^{a}$ & MIC & Peptide & MIC & Peptide & MIC & Peptide & MIC \\
\hline FRQXXX & 331 & FRLQXX & 161 & FRLKQX & $139 \pm 15$ & FRLKFQ & $10 \pm 0$ \\
\hline FRSXXX & 688 & FRLSXX & $160 \pm 4$ & FRLKSX & $>625$ & FRLKFS & $10 \pm 1$ \\
\hline FRFXXX & $63 \pm 2^{b}$ & FRLFXX & $40 \pm 2$ & $\overline{F R} \overline{L K} \bar{F} \bar{X}$ & $-\overline{10} \pm 0$ & FRLKFF & $5 \pm 0$ \\
\hline FRAXXX & 593 & FRLAXX & $162 \pm 2$ & $\bar{F} \bar{R} \overline{L K A} \bar{X}$ & $-\overline{76} \pm \overline{2}$ & FRLKFA & $10 \pm 0$ \\
\hline FRNXXX & 1,063 & FRLNXX & 161 & FRLKNX & $153 \pm 3$ & FRLKFN & $20 \pm 0$ \\
\hline FRWXXX & $82 \pm 2$ & FRLWXX & 288 & FRLKWX & $15 \pm 0$ & FRLKFW & $9 \pm 0$ \\
\hline FRVXXX & 139 & FRLVXX & 301 & FRLKVX & $10 \pm 0$ & FRLKFV & $9 \pm 1$ \\
\hline FRMXXX & $154 \pm 11$ & FRLMXX & 79 & FRLKMX & $20 \pm 0$ & FRLKFM & $10 \pm 0$ \\
\hline FRPXXX & 1,382 & FRLPXX & 315 & FRLKPX & $156 \pm 3$ & FRLKFP & $21 \pm 0$ \\
\hline FRHXXX & 534 & FRLHXX & $65 \pm 5$ & FRLKHX & $59 \pm 1$ & $\overline{\mathrm{FR}} \overline{\mathrm{LK}} \overline{\mathrm{F}} \overline{\mathrm{H}}$ & $5 \pm 0$ \\
\hline FRRXXX & 335 & FRLRXX & $67 \pm 4$ & FRLKRX & $40 \pm 0$ & $\overline{\mathrm{FR}} \overline{\mathrm{LK}} \overline{\mathrm{K}} \overline{\mathrm{F}}$ & $\overline{10} \pm \overline{0}$ \\
\hline FRIXXX & $79 \pm 3$ & FRLIXX & $73 \pm 4$ & FRLKIX & $10 \pm 0$ & FRLKFI & $5 \pm 0$ \\
\hline FRDXXX & $>2,500$ & FRLDXX & 637 & FRLKDX & $655 \pm 13$ & FRLKFD & $40 \pm 1$ \\
\hline FRCXXX & $* \mathrm{c}$ & FRLCXX & $*$ & FRLKCX & $20 \pm 0$ & FRLKFC & $10 \pm 1$ \\
\hline FRGXXX & 1,146 & FRLGXX & 484 & FRLKGX & $133 \pm 9$ & FRLKFG & $10 \pm 1$ \\
\hline FRTXXX & 555 & FRLTXX & $120 \pm 0$ & FRLKTX & $152 \pm 2$ & FRLKFT & $8 \pm 1$ \\
\hline FRKXXX & 511 & $\overline{F R} \overline{L K X} \bar{X}$ & $3 \overline{5} \pm 3$ & FRLKKX & $78 \pm 2$ & FRLKFK & $5 \pm 1$ \\
\hline FRLXXX & $68 \pm 9^{d}$ & FRLL $\bar{X} \bar{X}$ & $63 \pm 4$ & FRLKLX & $15 \pm 0$ & FRLKFL & $5 \pm 1$ \\
\hline FRE $\bar{X} \overline{X X}$ & $1,5 \overline{4} 7$ & FRLEXX & 316 & FRLKEX & $299 \pm 10$ & FRLKFE & $10 \pm 0$ \\
\hline FRYXXX & 633 & FRLYXX & $>2,500$ & FRLKYX & $32 \pm 2$ & FRLKFY & $5 \pm 0$ \\
\hline
\end{tabular}

${ }^{a}$ All peptide mixtures contain D-amino acids with the carboxyl terminal aminated

and the amino group unacetylated.

${ }^{b}( \pm)$ indicates the average of three replicate evaluations.

C Asterisk indicates that these mixtures were not synthesized.

${ }^{\mathrm{d}}$ Boxed peptide mixture from each series was chosen to construct the suceeding series. Boxed peptide mixture of the 66-series is the selected hexapeptide 66-10.

Table 4. Minimum inhibitory concentrations (MICs) $(\mu \mathrm{g} / \mathrm{ml})$ of the peptide mixture series constructed to obtain a defined antifungal hexapeptide against Pythium ultimum

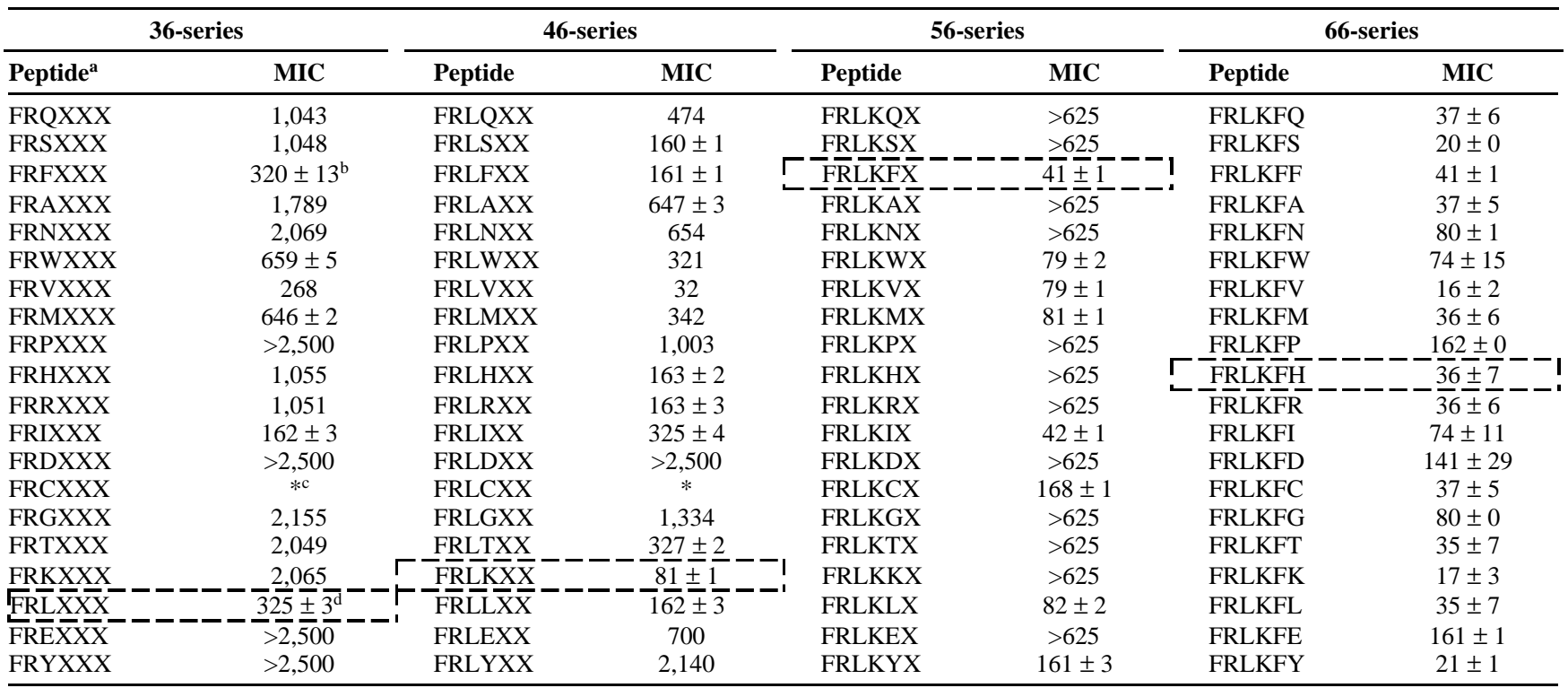

a All peptide mixtures contain D-amino acids with the carboxyl terminal aminated

and the amino group unacetylated.

b $( \pm)$ indicates the average of three replicate evaluations.

C Asterisk indicates that these mixtures were not synthesized.

${ }^{\mathrm{d}}$ Boxed peptide mixture from each series was chosen to construct the suceeding series. Boxed peptide mixture of the 66-series is the selected hexapeptide 66-10. 
stained with Sytox and incubated for $30 \mathrm{~min}$. In each treatment the impermeant dye entered the structure through the ethanol-treated (compromised) cytoplasmic membrane and stained the nuclear structure. The microscopic results are identical to those depicted in Figures 2A and 3A. It appears that the peptide is able to disrupt intact cytoplasmic and nuclear membranes, but is unable to act on ethanol-treated membranes. Identical results were obtained by exposing the ethanol-treated structures to a mixture of peptide and Sytox without an incubation period. Untreated spores of $F$. $o x$ ysporum f. sp. lycopersici and C. fagacearum in the presence of only Sytox showed no fluorescence (data not shown).

Figures 2C, 2D, and 2E show C. fagacearum spores treated with fluorescent brightener 28 only, ethanol-treated spores in the presence of fluorescent brightener 28 , and spores in the presence of fluorescent brightener 28 and hexapeptide 66-10, respectively. Figures $3 \mathrm{C}, 3 \mathrm{D}$, and $3 \mathrm{E}$ show the same treatments, respectively, with $F$. oxysporum f. sp. lycopersici microconidia. Since fluorescent brightener 28 stains the $1,4 \beta$ glucans of the cell wall it is evident that the cell wall is not disrupted by treatment with peptide or ethanol. Figures $2 \mathrm{~F}, 3 \mathrm{~F}$, and 4A show ethanol-treated-washed mycelial fragments of $C$. fagacearum, $F$. oxysporum f. sp. lycopersici, and $R$. solani (AG-1), respectively, that have been stained with Sytox. As with the spores or microconidia, there are defined, intact nuclei. Figures $2 \mathrm{G}, 3 \mathrm{G}$, and $4 \mathrm{~B}$ show mycelial fragments of the respective above-mentioned fungi in the presence of hexapeptide 66-10 and Sytox. As with Figures $2 \mathrm{~B}$ and 3B, the photographs indicate a loss of the defined, intact nucleus when the fungal structures are treated with 66-10. Figures $2 \mathrm{H}-\mathrm{J}, 3 \mathrm{H}-\mathrm{J}$, and $4 \mathrm{C}-\mathrm{E}$ show $C$. fagacearum, $F$. oxysporum f. sp. lycopersici, and $R$. solani (AG-1), respectively, treated differently and then stained with fluorescent brightener 28 . Figures $2 \mathrm{H}, 3 \mathrm{H}$, and $4 \mathrm{C}$ show mycelial fragments in the presence of fluorescent brightener 28 only. Figures 2I, 3I, and 4D show ethanoltreated-washed mycelial fragments in the presence of fluorescent brightener 28 . Figures $2 \mathrm{~J}, 3 \mathrm{~J}$, and $4 \mathrm{E}$ show mycelial fragments in the presence of fluorescent brightener 28 and hexapeptide 66-10. Again, all photographs depict an intact cell wall. Untreated mycelial fragments of $F$. oxysporum f. sp. $l y$ copersici, $C$. fagacearum, and $R$. solani in the presence of Sytox only showed no fluorescence (data not shown).

It was also determined from time course experiments with a 66-10, Sytox, and C. fagacearum spore mixture that $62 \%$ of the peptide-treated spores showed compromised membranes

Table 5. Minimum inhibitory concentrations (MICs) $(\mu \mathrm{g} / \mathrm{ml})$ of peptides PPD1 and 66-10 compared with selected antifungal agents against the designated fungal pathogens $\mathrm{s}^{\mathrm{a}}$

\begin{tabular}{|c|c|c|c|c|}
\hline $\begin{array}{l}\text { Antifungal } \\
\text { agent }\end{array}$ & $\begin{array}{c}\text { Fusarium } \\
\text { oxysporum } \\
\text { f. sp. } \\
\text { lycopersici }\end{array}$ & $\begin{array}{l}\text { Rhizoctoni } \\
\text { solani }\end{array}$ & $\begin{array}{l}\text { Ceratocystis } \\
\text { fagacearum }\end{array}$ & $\begin{array}{l}\text { Pythium } \\
\text { ultimum }\end{array}$ \\
\hline PPD1 & $66 \pm 2$ & $66 \pm 2$ & $14 \pm 3$ & $55 \pm 12$ \\
\hline $66-10$ & $19 \pm 1$ & $20 \pm 3$ & $5 \pm 0$ & $36 \pm 7$ \\
\hline $\mathrm{MBC}^{\mathrm{b}}$ & $2 \pm 0$ & $2.1 \pm 0.2$ & $1 \pm 0$ & $>2.5$ \\
\hline Cycloheximide & $38 \pm 1$ & $0.7 \pm 0.1$ & $0.4 \pm 0$ & $6 \pm 1$ \\
\hline Nystatin $^{c}$ & $5 \pm 0.4$ & $2.1 \pm 0$ & $1 \pm 0$ & $>100$ \\
\hline
\end{tabular}

a MICs represent the average of three independent evaluations \pm the standard deviations.

${ }^{\mathrm{b}}$ Methyl-(butylcarbamoyl)-2-benzimidazole-2yl carbamate.

c $1 \mu \mathrm{g}=5.160$ units within $5 \mathrm{~min}$. By $15 \mathrm{~min}, 99 \%$ of the spores present showed confluent fluorescent staining and had lost the defined internal nuclear structure, indicating that a majority of the fungal structures had been compromised. In addition to fluorescent microscopy experiments to determine the time required for 66-10 to act, dilution plating experiments were performed to determine the kill-time of 66-10. Within $15 \mathrm{~min}, 70 \%$ of the compromised $C$. fagacearum spores were incapable of germination on PDA. By $60 \mathrm{~min}, 88 \%$ of the structures had become nonviable.

\section{Mutagenic potential of bioactive peptides.}

The mutagenic potential of pentapeptide PPD1 and hexapeptide 66-10 was determined with the Ames Salmonella plate incorporation assay. Strains TA98 and TA100 were used to evaluate a serial dilution series (300 to $9.37 \mu \mathrm{g} / \mathrm{ml}$ ). In two independent assays, the defined peptides PPD1 and 66-10 showed no mutagenic properties at all concentrations tested, with and without metabolic activation. Both TA98 and TA100 cells exposed to the known mutagens 2-nitrofluorene or 2aminofluorene without activation and benzo(a)pyrene or 2aminofluorene with activation showed the expected twofold or better increase in the reversion rate over that observed in negative controls. Under conditions of the Ames test there were no indications of a toxic effect to the test strains by either peptide, since the reversion numbers for the controls and all tested concentrations of the peptide were similar.

\section{Hemolytic activity of the defined hexapeptide 66-10.}

The hemolytic activity of hexapeptide 66-10, mellitin, and Triton X-100 (0.1\%) was determined with human, bovine, and ovine red blood cells (Table 6). The anionic detergent Triton X-100 yielded $100 \%$ lysis of all the respective red blood cells. The bee venom, mellitin, a 23-amino acid peptide and a known hemolytic agent, was tested at a concentration range from 100 to $0 \mu \mathrm{g} / \mathrm{ml}$. Mellitin showed lysis of the tested red blood cells at a concentration as low as $0.1 \mu \mathrm{g} / \mathrm{ml}$. Hexapeptide 66-10 was tested at a range from 312 to $0 \mu \mathrm{g} / \mathrm{ml}$ and showed no hemolytic activity with the respective red blood cells.

\section{Absorption studies.}

To determine if hexapeptide 66-10 inserts reversibly into the fungal membrane, absorption studies were performed with C. fagacearum spores. Comparison of the titered control of hexapeptide 66-10 to the experimental sample containing $C$. fagacearum spores showed $7 \%$ remaining in the spore pellet. Washing of the spore pellet, however, recovered the amount that was bound. The bound peptide in combination with that found in the supernatant accounted for the total amount that was added. The controls with glass beads and latex polystyrene beads in place of the $C$. fagacearum spores showed no detectable, nonspecific binding of hexapeptide 66-10 to either hydrophobic or hydrophilic surfaces.

\section{DISCUSSION}

Evaluation of the synthetic peptide combinatorial libraries identified a biologically active hexapeptide that appears to rapidly compromise the cell membranes of $F$. oxysporum $\mathrm{f}$. sp. lycopersici, $R$. solani (AG-1), C. fagacearum, and P. ultimum, 
and that shows no nonspecific binding, hemolytic, or mutagenic activity. The biological activity of amphipathic $\alpha$-helical peptides is thought to result from their ability to form ion channels through membrane bilayers (Lear et al. 1988; Anzai et al. 1991) and a length of approximately 20 amino acid residues is necessary to completely span the hydrocarbon portion of the lipid bilayer (Lear et al. 1988). Peptides PPD1 (FRLHF) and 66-10 (FRLKFH) are small, cationic, basic peptides, with hydrophobic backbones that are smaller than known antimicrobial peptides from natural sources (Maloy and Kari 1995; Rao 1995). However, studies show that short, cationic peptides ( 8 to 12 peptides in length) can form ion
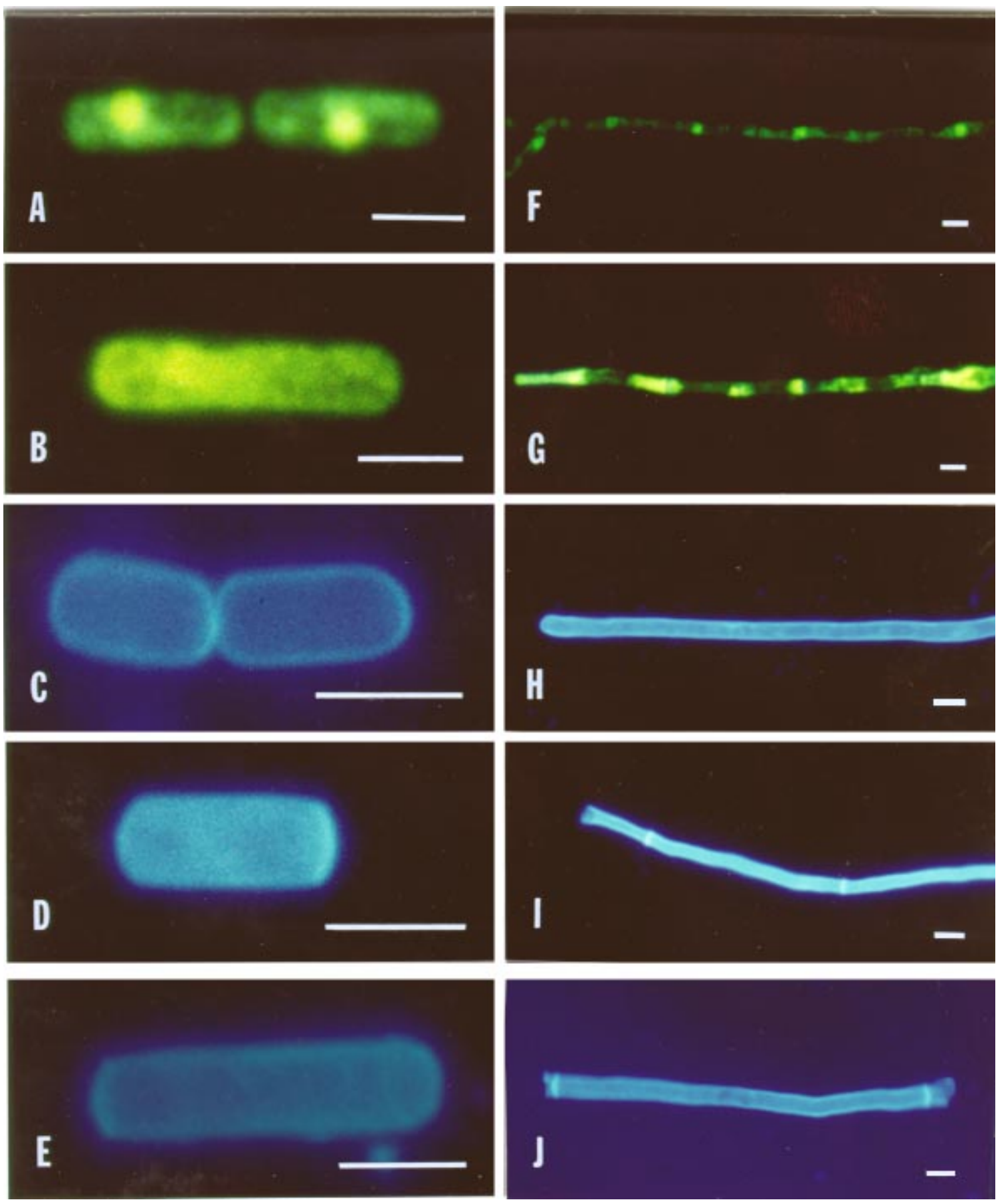

Fig. 2. Fluorescent staining of Ceratocystis fagacearum spores and hyphae with the membrane impermeant Sytox Green nucleic acid stain or the cell wall stain fluorescent brightener 28 in the presence or absence of hexapeptide 66-10 or ethanol treatment. A, Ethanol-treated spores in the presence of Sytox. B, Spores in the presence of Sytox and hexapeptide 66-10. C, Spores treated with fluorescent brightener 28 only. D, Ethanol-treated spores in the presence of fluorescent brightener 28. E, Spores in the presence of fluorescent brightener 28 and hexapeptide 66-10. F, Ethanol-treated mycelial fragments in the presence of Sytox. G, Mycelial fragments in the presence of Sytox and hexapeptide 66-10. H, Mycelial fragments in the presence of fluorescent brightener 28 only. I, Ethanol-treated mycelial fragments in the presence of fluorescent brightener 28 . J, Mycelial fragments in the presence of fluorescent brightener 28 and hexapeptide 66-10. Bars represent $5 \mu \mathrm{m}$. 
channels (Anzai et al. 1991). Bessalle et al. (1993) reported that short peptides with a high hydrophobic and basic nature have appreciable bioactivity. They stated that, due to their small size, short peptides cannot span the lipid bilayer, and they suggested different mechanisms of action for long-chain versus short-chain peptides. Anzai et al. (1991) and Agawa et al. (1991) postulated oligomeric bundles of head-to-tail dimers of short peptides as a potential explanation for their activity.

The initial interaction between the peptide and the target microorganism is presumably of an electrostatic nature
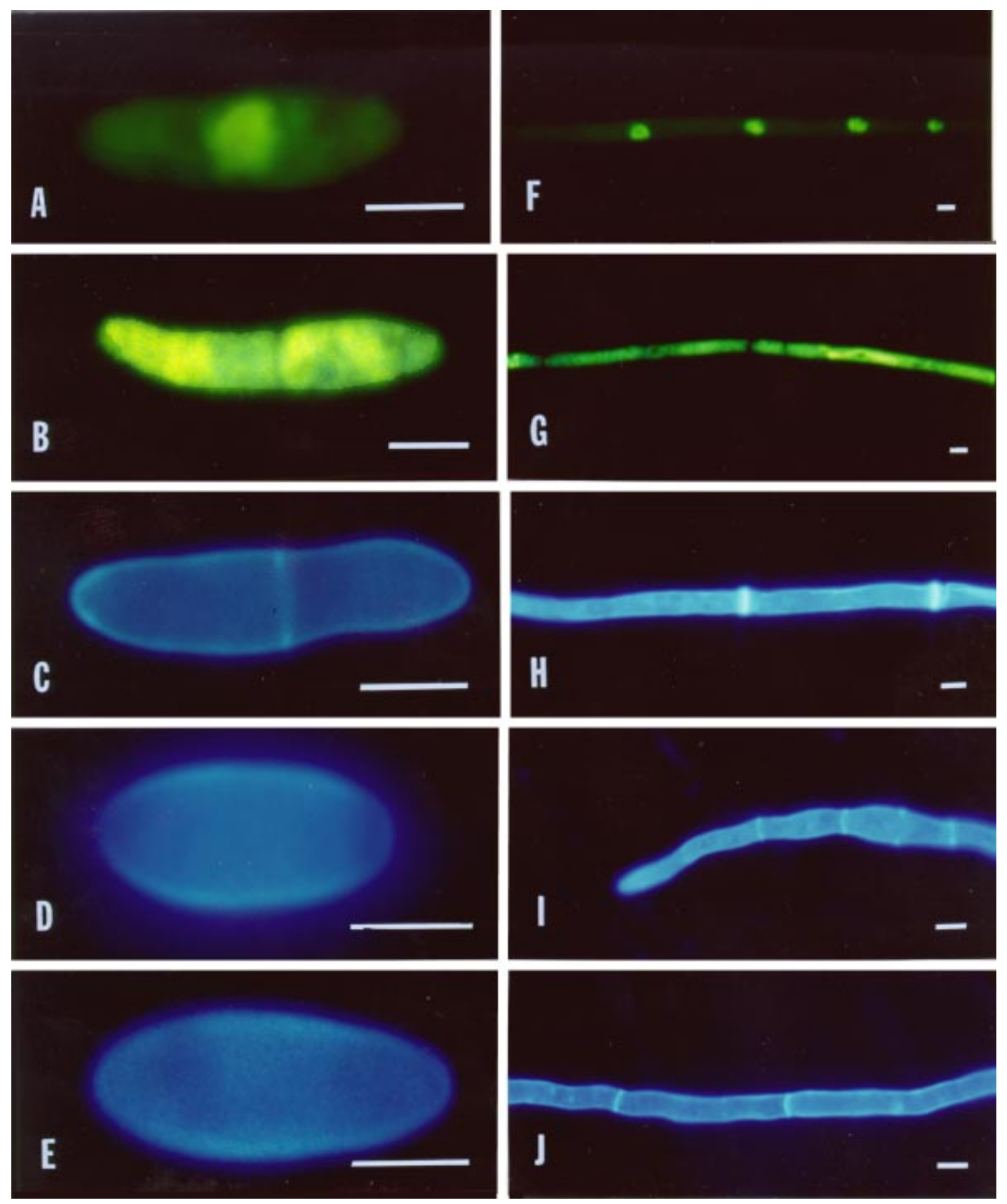

Fig. 3. Fluorescent staining of Fusarium oxysporum f. sp. lycopersici microconidia and hyphae with the membrane impermeant Sytox Green nucleic acid stain or the cell wall stain fluorescent brightener 28 in the presence or absence of hexapeptide 66-10 or ethanol treatment. A, Ethanol-treated microconidia in the presence of Sytox. B, Microconidia in the presence of Sytox and hexapeptide 66-10. C, Microconidia treated with fluorescent brightener 28 only. D, Ethanol-treated microconidia in the presence of fluorescent brightener 28 . E, Microconidia in the presence of fluorescent brightener 28 and hexapeptide 66-10. F, Ethanol-treated mycelial fragments in the presence of Sytox. G, Mycelial fragments in the presence of Sytox and hexapeptide 6610. H, Mycelial fragments in the presence of fluorescent brightener 28 only. I, Ethanol-treated mycelial fragments in the presence of fluorescent brightener 28. J, Mycelial fragments in the presence of fluorescent brightener 28 and hexapeptide 66-10. Bars represent $5 \mu \mathrm{m}$. 

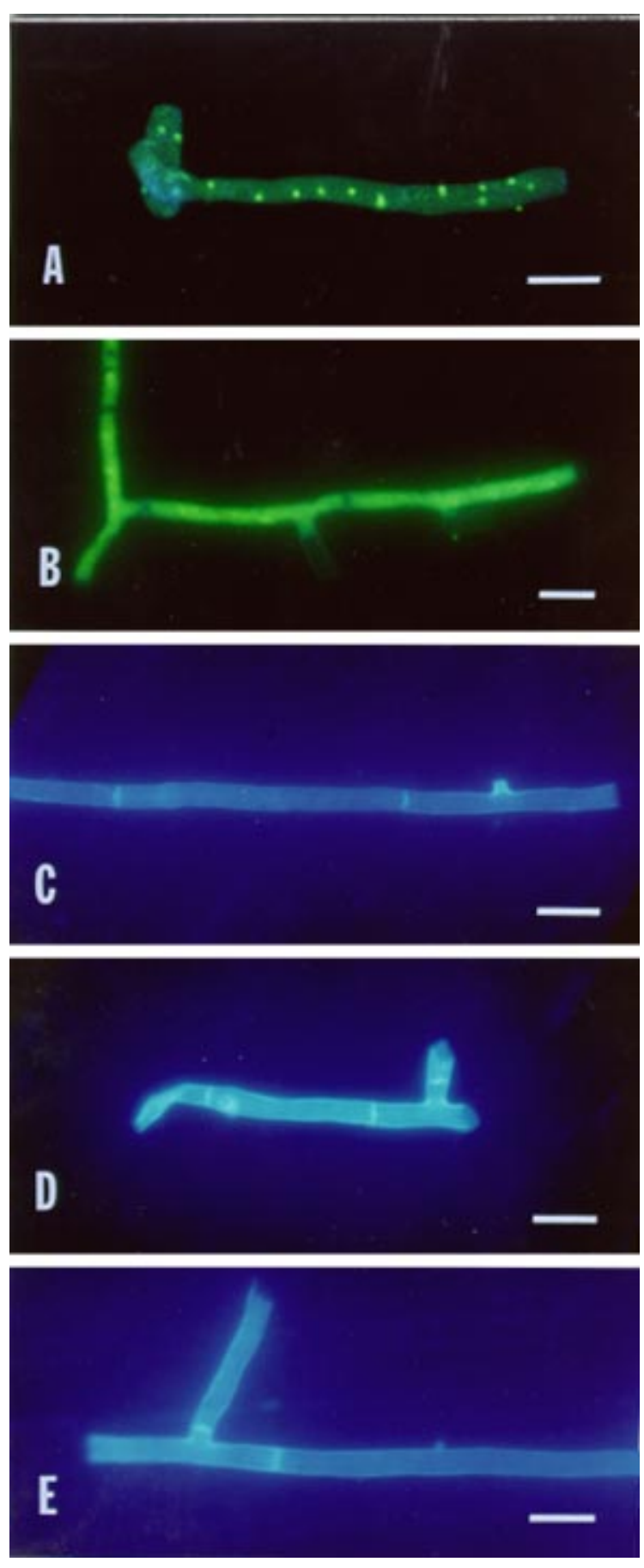

Fig. 4. Fluorescent staining of Rhizoctonia solani (AG-1) mycelial fragments with the membrane impermeant Sytox Green nucleic acid stain or the cell wall stain fluorescent brightener 28 in the presence or absence of hexapeptide 66-10 or ethanol treatment. A, Ethanol-treated mycelial fragments in the presence of Sytox. B, Mycelial fragments in the presence of Sytox and hexapeptide 66-10. C, Mycelial fragments treated with fluorescent brightener 28 only. D, Ethanol-treated mycelial fragments in the presence of fluorescent brightener 28. E, Mycelial fragments in the presence of fluorescent brightener 28 and hexapeptide 66-10. Bars represent $20 \mu \mathrm{m}$.
(Bessalle et al. 1993). The pentapeptide PPD1 contains two terminal Phe residues at positions 1 and 5, a Leu residue at position 3, and Arg and His residues at positions 2 and 4, respectively. Similarly, hexapeptide 66-10 also contains Phe residues at positions 1 and 5, a Leu residue at position 3, and Arg, Lys, and His residues at positions 2, 4, and 6, respectively. The developed peptides exhibit a cationic, hydrophobic character that is prevalent in other antimicrobial peptides (Agawa et al. 1991; Bessalle et al. 1993; Blondelle and Houghten 1992; Evans and Harmon 1995). The cationic character of the naturally occurring peptides appears to allow for a strong interaction between the peptide and the negatively charged phospholipids of cell membranes (Agawa et al. 1991), which might also be the operational mechanism for the peptides described herein. Cationicity is conferred to the peptides by the presence of positively charged amino acids arginine, lysine, and/or histidine. Also, the hydrophobic residues Phe and Leu that separate the positively charged residues of the peptides enhance the capabilities of the charged residues to interact with the hydrophobic chains of the phospholipids.

Cecropins B and D, isolated from the pupae of the Chinese oak silk moth (Antheraea pernyi) contain 46 and 24\%, respectively, of the aforementioned amino acids in their primary sequences (Qu et al. 1982). Forty-eight percent of the primary sequence of magainins I and II contain either Phe, Ile, Leu, His, or Lys, and contribute to their antimicrobial properties (Maloy and Kari 1995). Approximately $50 \%$ of the primary sequence of various defensins also consist of these same hydrophobic or cationic amino acids (Ganz and Lehrer 1995). It becomes apparent that a cationic, hydrophobic character is important for expression of significant antimicrobial activity. At the $\mathrm{pH}$ used for our in vitro assay ( $\mathrm{pH}$ 6.0) the His, Lys (only 66-10), and Arg residues are fully protonated $(\mathrm{pKa}=6.7,10$, and 12 , respectively), thus giving the peptides a positive charge that appears to be associated with the potency of peptides. Powell et al. (1995) reported MICs of $2.5,15$, and $20 \mu \mathrm{M}$ for $F$. oxysporum f. sp. lycopersici with peptides ESF1 (20 residues), magainin II (23 residues), and cecropin B (35 residues), respectively. Although we did not use the same isolate, we observed in replicate experiments an MIC of $22 \mu \mathrm{M}$ for F. oxysporum f. sp. lycopersici with peptide 66-10. On a molar basis the activity of the hexapeptide compares well with that of cecropin B, but not with that of ESF1 or magainin II.

Activity of the peptides was directly compared with MBC, cycloheximide, or nystatin, with all antifungals having different modes of action (Jawetz et al. 1982; McGinnis and Rinaldi

Table 6. Hemolytic activity of hexapeptide 66-10, mellitin, and Triton $\mathrm{X}-100$

\begin{tabular}{lrcr}
\hline & \multicolumn{3}{c}{ Red blood cells } \\
\cline { 2 - 3 } Compound & Human & Bovine & Ovine \\
\cline { 2 - 3 } Hemolysis (\%) \\
\hline $66-10$ & & & \\
312 to $0 \mu \mathrm{g} / \mathrm{ml}$ & 0 & 0 & 0 \\
Mellitin & & & \\
100 to $10 \mu \mathrm{g} / \mathrm{ml}$ & 100 & 100 & 100 \\
$5 \mu \mathrm{g} / \mathrm{ml}$ & 98 & 100 & 86 \\
$1 \mu \mathrm{g} / \mathrm{ml}$ & 95 & 3 & 7 \\
$0.1 \mu \mathrm{g} / \mathrm{ml}$ & 11 & 2 & 4 \\
$0 \mu \mathrm{g} / \mathrm{ml}$ & 0 & 0 & 0 \\
Triton X-100 $(0.1 \%)$ & 100 & 100 & 100 \\
\hline
\end{tabular}


1991; Pinto et al. 1993). F. oxysporum f. sp. lycopersici and $R$. solani (AG-1) were sensitive to each of the antimicrobials tested. P. ultimum, however, was insensitive to $\mathrm{MBC}$ and nystatin, as previously documented (Williams and Ayanaba 1975; Kerwin and Duddles 1989; Hancock 1993). Hexapeptide 66-10 was approximately 3 to 10 times lower in activity than the commercial antifungals, with the exception of cycloheximide against $F$. oxysporum f. sp. lycopersici. Cycloheximide exhibited $2 \times$ lower activity than 66-10 against $F$. oxysporum f. sp. lycopersici. Compared with 66-10, PPD1 showed less activity against the test fungi. This may be explained by the fact that $66-10$ contains 6 amino acids, whereas PPD1 contains 5 amino acids. Of the test fungi, $C$. fagacearum was the most sensitive to all the antifungals tested, including the synthetic peptides 66-10 and PPD1. This was observed throughout the development of the peptides, and may indicate that $C$. fagacearum may have unique features in the structure of its membrane, making it more susceptible to peptide action.

During the development of new antimicrobials it is important to determine if a compound may possess mutagenic or hemolytic activity. The Salmonella plate incorporation assay (Ames et al. 1973), with and without microsomal activation, demonstrated that neither PPD1 nor 66-10 possessed mutagenic properties at a concentration as high as $300 \mu \mathrm{g} / \mathrm{ml}$ based on the twofold rule of Chu et al. (1981). In a study to determine the potential for the formation of ion channels through cell membranes by an amphipathic peptide, Blondelle and Houghten (1992) evaluated the peptide AC-LKLLKKLLKKL KKLLKKL- $\mathrm{NH}_{2}$ through the preparation of analogs that varied in length from 8 to 22 residues while maintaining amphipathicity. They found that hemolytic activity was more sequence dependent than lysis of bacterial cells and suggested that two different mechanisms of action were involved in the lysis of bacteria and red blood cells. Stronger hydrophobic interactions than that necessary for antimicrobial activity were shown to be necessary for the lysis of red blood cells. Additionally, they found that as they reduced the peptide length while maintaining amphipathicity, hemolytic activity was reduced and antimicrobial activity varied with the bacterial isolate. They observed no hemolytic activity with peptides smaller than 12 residues. This was consistent with the lack of hemolytic activity observed with 66-10 at concentrations up to $312 \mu \mathrm{g} / \mathrm{ml}$. These two tests are critical first steps in the development of a chemical that could be introduced into the environment.

The fluorescent microscopy experiments with the membrane impermeant dye Sytox strongly suggest that 66-10 compromises the integrity of the cell membrane and, in addition, affects the nuclear membrane (Figures $2 \mathrm{~B}$ and $\mathrm{G}, 3 \mathrm{~B}$ and $\mathrm{G}$, and 4B). It is also evident that the ethanol-treated structures are infiltrated by Sytox, but that the nuclear structure is not disrupted (Figures 2A and F, 3A and F, and 4A). This indicates that an intact or biologically active membrane may be necessary for the peptide to act. The ethanol treatment acts to compromise the membrane in a manner (dehydration) that makes it no longer susceptible to peptide action. The highly cationic, hydrophobic peptide, 66-10, is certainly not long enough to span the membrane. However, its structure might allow for a limited $\alpha$-helical formation. Although we can only speculate on the exact mode of action for the peptide, we know that the interaction takes place in a manner that results in 62 and $99 \%$ of treated C. fagacearum spores having a compromised membrane in 5 and $15 \mathrm{~min}$, respectively. This, along with a $70 \%$ kill rate within $15 \mathrm{~min}$ of exposure of spores to the peptide, illustrates the rapid manner in which the peptide acts. The rapid effect observed is consistent with an interaction of the peptide and the membrane phospholipids, as discussed above.

Combinatorial chemistry offers a systematic method for the development of antimicrobial peptides that show high broadspectrum activity against an array of microorganisms. The observed high broad-spectrum activity of the identified small peptides warrants further investigation to elucidate possible mechanisms of action and alternate expression systems.

\section{MATERIALS AND METHODS}

\section{Fungal strains and media used in the study.}

The fungal strains used in this study were Fusarium oxysporum Schlechtend.:Fr. f. sp. lycopersici (Sacc.) W. C. Snyder \& H. N. Hans., race 1, strain RM1, obtained from R. D. Martyn, Texas A\&M University (TAMU) (FOLRM-1); Rhizoctonia solani Kühn strain TM-101, anastomosis group 1, obtained from M. A. Marchetti, USDA-Beaumont, TX (RS101); Rhizoctonia solani, anastomosis group 4, obtained from J. Johnk, TAMU Research Center, Dallas, TX; Pythium ultimum Trow strain LB-1, isolated from cotton, obtained from L. Barnes, TAMU (PULB-1); Ceratocystis fagacearum (T. W. Bretz) J. Hunt strain BAN 102 (CFBAN-102), and Ophiostoma ulmi (Buisman) Nannf. (OU-1) obtained from D. N. Appel, TAMU. All cultures were routinely transferred to potato dextrose agar (PDA) (Difco, Detroit, MI) plates. Potato dextrose broth (PDB) (Difco) was used in all microtiter plate studies. Clarified V8-cholesterol broth, as described by Ayers and Lumsden (1975), was used for oospore production by $P$. ultimum. A mineral salts medium (FLC), as described by Esposito and Fletcher (1961), was used for microconidia production by $F$. oxysporum f. sp. lycopersici.

\section{Growth and storage conditions for stock cultures and production of inoculum for bioassays.}

All fungal cultures were grown at $25^{\circ} \mathrm{C}$ and routinely maintained on PDA plates. The plates were stored at $4^{\circ} \mathrm{C} . R$. solani and $P$. ultimum were maintained as mycelial cultures on PDA. F. oxysporum f. sp. lycopersici was stored as microconidia that were produced in FLC medium. Microconidia were produced as follows with the FLC medium. A 4-mm square of an actively growing culture was taken from PDA to $50 \mathrm{ml}$ of FLC broth in a sterile, 250-ml, screw-cap flask. The culture was incubated with shaking (200 rpm; model 4710, Queue Systems, Parkersburg, WV) at $25^{\circ} \mathrm{C}$. After $96 \mathrm{~h}$, the slurry of mycelia and microconidia was filtered twice through 3 layers of sterile cheesecloth to obtain the microconidial suspension. The microconidial suspension was adjusted to a concentration of 1 to $5 \times 10^{7}$ microconidia/ml with a Brightline hemacytometer (Hausser Scientific, Horsham, PA) and was frozen in 1-ml aliquots in $20 \%$ sterile glycerol at $-80^{\circ} \mathrm{C}$. C. fagacearum spores were harvested from PDA plates that were incubated at $25^{\circ} \mathrm{C}$ for 8 days. The spores were harvested in sterile PDB, filtered, adjusted to a concentration of 1 to $5 \times$ $10^{7}$ spores per $\mathrm{ml}$, and stored as described above. 
Frozen glycerol stocks of $F$. oxysporum f. sp. lycopersici microconidia and C. fagacearum spores were used for the bioassays. Microconidia or spores were thawed on ice, washed $2 \times$ in PDB, and diluted in PDB to obtain the appropriate inoculum concentration for the assay. Inoculum of $R$. solani consisted of mycelial fragments that were prepared from an actively growing broth culture. To obtain these fragments, a single sclerotium from an actively growing culture was inoculated to $50 \mathrm{ml}$ of sterile PDB in a $250-\mathrm{ml}$, sterile, screwcap, Erlenmeyer flask and incubated with shaking (125 rpm; model 4710, Queue Systems, Parkersburg, WV) at $25^{\circ} \mathrm{C}$. After 4 days, the mycelial mass had grown to approximately 2 $\mathrm{cm}$ in diameter and was divided in the flask by a sterile glass pipette. One half was removed and placed into a sterile tissue grinder (\#7725-19, Corning Glass Works, Scientific Products Division, Corning, NY). The mycelial mass was macerated in PDB ( $5 \mathrm{ml})$ on ice to obtain fragments with an average size of $52 \mu \mathrm{m}$ (average of 100 mycelial fragments). The mycelial fragment suspension was calibrated with a hemacytometer and adjusted to 3 to $5 \times 10^{4}$ mycelial fragments per $\mathrm{ml}$ of PDB for the bioassay experiments. Inoculum of $P$. ultimum consisted of oospores produced from an actively growing culture. A PDA plug of an actively growing culture of $P$. ultimum was inoculated to $20 \mathrm{ml}$ of sterile V8-cholesterol broth (Ayers and Lumsden 1975) in sterile, glass, petri dishes and incubated at $21^{\circ} \mathrm{C}$. After 10 days, the mycelial mat was washed 2 times in sterile, deionized water. The mycelial mat was divided in half and each half was macerated with a hand-held homogenizer as described for $R$. solani. After maceration, the suspension of oospores was filtered through 3 layers of sterile cheesecloth. The oospore suspension was calibrated with a hemacytometer and diluted to the proper inoculum concentration with sterile PDB. An aliquot of the prepared microconidial, spore, mycelial fragment, or oospore suspension was streaked to a tryptone nutrient agar (Olsen and Hansen 1976) plate. The plates were incubated at $25^{\circ} \mathrm{C}$ for $24 \mathrm{~h}$ to verify that the suspensions were bacteria-free.

\section{Determination of optimum inoculum concentration and incubation conditions for bioassay.}

All of the fungal isolates were inoculated to sterile, disposable, flat-bottom, polystyrene, 96-well (with lid), microtiter plates (Corning Glass Works) for growth studies in order to determine the optimum conditions for the bioassay. Parameters such as optimal inoculum concentration, temperature, length, and method of incubation were determined to obtain optical density readings over the growth period that was reflective of balanced growth conditions. Balanced growth conditions were defined as those conditions that allowed for a short lag phase, an exponential phase, and a stationary phase of growth.

F. oxysporum f. sp. lycopersici microconidia and spores from $C$. fagacearum were inoculated to 96-well microtiter plates. Frozen stocks of the microconidia or spores were removed from the $-80^{\circ} \mathrm{C}$ freezer and allowed to thaw on ice. Each suspension was washed $2 \times$ in PDB and then diluted to obtain an inoculum concentration in the range of 1 to $7 \times 10^{5}$ microconidia or spores per $\mathrm{ml}$. The inoculum was stored on ice until needed. The microtiter plates were aliquoted with 50 $\mu \mathrm{l}$ of PDB per well and $50 \mu \mathrm{l}$ of the microconidia or spore inoculum per well. Wells A1 to A3 (media control wells) re- ceived $100 \mu \mathrm{l}$ of PDB. All of the microtiter plates were incubated both with and without shaking, in the dark, at $25^{\circ} \mathrm{C}$, for up to $96 \mathrm{~h}$. To follow growth in the microtiter plates, an Emax Precision Microplate Reader (Molecular Devices, Menlo Park, CA) attached to a Think-Jet printer (Hewlett-Packard, Vancouver, WA) was used to obtain the absorbance (at $595 \mathrm{~nm}$ ) readings, which were recorded at 24-h intervals.

A mycelial fragment suspension of $R$. solani was prepared as previously described. PDB was aliquoted into microtiter wells, as described above, that were individually inoculated with $50 \mu \mathrm{l}$ of the respective mycelial suspensions of $3 \times 10^{4}$ or $3 \times 10^{5}$ mycelial fragments per $\mathrm{ml}$. All microtiter plates were incubated with and without shaking, at $25^{\circ} \mathrm{C}$, in the dark, for $96 \mathrm{~h}$. Absorbance readings were recorded on a 24-h regime.

For $P$. ultimum growth studies, an oospore suspension was obtained as described. The stocks were diluted in PDB to obtain a final concentration of $6.6 \times 10^{4}$ or $3.4 \times 10^{5}$ oospores per ml. Microtiter plates were aliquoted with $50 \mu \mathrm{l}$ of PDB and then inoculated with $50 \mu \mathrm{l}$ per well of the respective oospore suspensions. All microtiter plates were incubated with and without shaking, in the dark, at $25^{\circ} \mathrm{C}$, for $72 \mathrm{~h}$. Absorbance readings were recorded.

Once growth conditions were determined, absorbance versus dry weight correlations were resolved for each of the fungal isolates. Briefly, all microtiter plates were inoculated as described earlier and incubated without shaking. At each time interval, the contents of 22 wells were collected and combined to form one sample. The sample was vacuum filtered through a pre-weighed, 0.45- $\mu \mathrm{m}$, glass filter (Millipore, Bedford, CT). The filter was dried at $15 \mathrm{in} . \mathrm{Hg}(1 \mathrm{in} .=2.54 \mathrm{~cm})$, in a $70^{\circ} \mathrm{C}$ Thelco vacuum oven (Precision Scientific, Chicago, IL) to constant weight. The dried filters were allowed to come to room temperature in a vacuum desiccator. The tared weight of the filter was subtracted from the sample-filter weight to determine mycelial mass dry weight. At each time interval, the dry weight was calculated as mg per well. Absorbance readings, for each of the 22 wells collected at each time interval, were averaged.

\section{Development of a defined antimicrobial hexapeptide.}

The starting peptide mixture library, designated 26-series, was synthesized by Houghten Laboratories (Torrey Pines Institute for Molecular Studies, San Diego, CA), using a process described by Houghten et. al. (1992). The 26-series peptide library was prepared with methylbenzhydrylamine polystyrene resin and standard t-Boc chemistry in combination with simultaneous multiple peptide synthesis. Each mixture in the 26-series library consists of six positions. The first two positions each consist of individual D-amino acids, while the remaining four positions each consist of an equimolar mixture of 19 D-amino acids. Cysteine was omitted from the mixture position because a reducing agent is needed and it is difficult to define disulfide aggregates. The peptide mixture libraries employed in the iterative steps, following screening of the 26series, were synthesized in a similar manner by Quality Controlled Biochemicals (Hopkinton, MA). The designated amino acids for each series were based on the bioassay results of the previous series.

The antimicrobial activity of the initial 400 peptide mixture library (26-series) and those libraries involved in the iterative steps was determined with a 96-well microtiter plate bioassay 
under established conditions. F. oxysporum f. sp. lycopersici and $R$. solani were used to screen the entire 26-series. All four fungal isolates were used to retest selected 26-series peptide mixtures and peptide mixtures involved in the iterative steps. Fifty microliters of $1 \times$ PDB was added to all wells of a 96well microtiter plate, except A1 to A3 and B1 to H1. Wells A1 to $\mathrm{A} 3$ (media control) received $100 \mu \mathrm{l}$ of $1 \times \mathrm{PDB}$ to function as media control wells. Wells B1 to $\mathrm{H} 1$ received $50 \mu \mathrm{l}$ of $2 \times$ PDB. Wells A4 to A12 were designated growth control and received no test compound. The individual aqueous peptides or peptide mixtures were added to each of wells B1 to $\mathrm{H} 1$ in $50-\mu \mathrm{l}$ aliquots and a twofold serial dilution was carried out across each row with a starting concentration of either 2,500, 1,250 , or $625 \mu \mathrm{g} / \mathrm{ml}$ and an ending concentration of either $1.25,0.625$, or $0.313 \mu \mathrm{g} / \mathrm{ml}$, respectively. Once the individual peptide mixtures had been diluted across each row, the microtiter plate (excluding wells A1 to A3) was overlaid with 50 $\mu \mathrm{l}$ of the selected fungal inoculum. The inoculum was prepared as described earlier. Absorbance readings (at $595 \mathrm{~nm}$ ) were taken at $0,24,48$, and $72 \mathrm{~h}$ for $F$. oxysporum f. sp. $l y$ copersici, $R$. solani, and $P$. ultimum, with an additional reading at $96 \mathrm{~h}$ for $C$. fagacearum.

After the 26-series peptide mixture library, tested in a single dilution series, was screened for antimicrobial activity, an iterative process was employed to develop the defined antimicrobial hexapeptide. The starting library contained individual mixtures with a sequence of $\mathrm{O}_{1} \mathrm{O}_{2} \mathrm{XXXX}$. Positions $\mathrm{O}_{1}$ and $\mathrm{O}_{2}$ were specifically defined amino acids and each $\mathrm{X}$ position represented an equimolar mixture of 19 amino acids (cysteine omitted). The 400 mixtures resulted from all possible combinations involving positions $\mathrm{O}_{1}$ and $\mathrm{O}_{2}$ (i.e., 20 $0^{2}=400$ ). The 26-series peptide mixture that exhibited the highest broadspectrum activity for the microorganisms tested was chosen to construct the 36-series consisting of positions $\mathrm{O}_{1} \mathrm{O}_{2} \mathrm{O}_{3} \mathrm{XXX}$. Positions $\mathrm{O}_{1}$ and $\mathrm{O}_{2}$ were those determined in the 26-series peptide mixture and position $\mathrm{O}_{3}$ consisted of one of 19 Damino acids (cysteine omitted). Each $\mathrm{X}$ position represented an equimolar mixture of 19 amino acids (cysteine omitted). Following screening of the 36 -series, the peptide mixture that exhibited the highest broad-spectrum activity was chosen to construct the 46-series consisting of positions $\mathrm{O}_{1} \mathrm{O}_{2} \mathrm{O}_{3} \mathrm{O}_{4} \mathrm{XX}$. The 56-series and 66-series with positions $\mathrm{O}_{1} \mathrm{O}_{2} \mathrm{O}_{3} \mathrm{O}_{4} \mathrm{O}_{5} \mathrm{X}$ and $\mathrm{O}_{1} \mathrm{O}_{2} \mathrm{O}_{3} \mathrm{O}_{4} \mathrm{O}_{5} \mathrm{O}_{6}$ defined were synthesized by following the same strategy.

\section{Analysis of data.}

For each peptide mixture, the data was expressed as a minimum inhibitory concentration (MIC). The MIC was defined as the lowest concentration of the test peptide at which there was no growth. Some data were expressed as a $50 \%$ inhibitory concentration $\left(\mathrm{IC}_{50}\right)$. The $\mathrm{IC}_{50}$ was defined as that concentration of the test peptide or peptide mixture that inhibited $50 \%$ of growth. To obtain the MIC and $\mathrm{IC}_{50}$, absorbance readings from the final time interval were used to calculate the percent inhibition of growth. For all microtiter plates, absorbance values of nine control wells (A4 to A12) were averaged. The average absorbance value obtained for wells A4 to A12 was individually divided into the absorbance values obtained for the dilution series of a particular peptide or peptide mixture. Then, each value was subtracted from 100 to acquire the percent inhibition. By using percent inhibition as $x$ values and peptide concentration as $y$ values, linear regression analysis was performed on each peptide mixture. The $y$ intercept, $n$, correlation coefficient, $\mathrm{MIC}$, and $\mathrm{IC}_{50}$ were calculated for each peptide or peptide mixture. The MIC or $\mathrm{IC}_{50}$ data were expressed as the mean of three replicates \pm the standard deviation, where replicates were performed.

\section{Comparison of defined hexapeptide to antifungal agents.}

The defined hexapeptide, designated 66-10, and pentapeptide, designated PPD1, were compared with cycloheximide (Sigma Chemical, St. Louis, MO), nystatin (Sigma), and MBC (methyl-(butylcarbamoyl)-2-benzimidazole-2yl carbamate; $99.6 \%$ active; Dupont De Nemours, Wilmington, DE) for antifungal activity. These studies were performed, in triplicate, for all fungal isolates, using the protocol as described for the peptide assays. All fungal isolates were exposed to MBC at a concentration range of 2.5 to $0.0012 \mu \mathrm{g} / \mathrm{ml}$. F . oxysporum f. sp. lycopersici, $R$. solani, and C. fagacearum were tested for growth inhibition by nystatin at a concentration range of 50 to $0.025 \mu \mathrm{g} / \mathrm{ml}$, whereas $P$. ultimum was tested at a concentration range of 100 to $0.050 \mu \mathrm{g} / \mathrm{ml}$. F. oxysporum f. sp. lycopersici, $R$. solani, and $P$. ultimum were tested against cycloheximide at a concentration range of 50 to $0.006 \mu \mathrm{g} / \mathrm{ml}$, and $C$. fagacearum was tested at a concentration range of 250 to 0.061 $\mu \mathrm{g} / \mathrm{ml}$. MICs were calculated as previously described.

\section{Determination of potential target site of hexapeptide 66-10.}

Spores and mycelial fragments from $F$. oxysporum f. sp. $l y$ copersici and $C$. fagacearum, and mycelial fragments from $R$. solani, were used to determine the potential target of 66-10. The fluorescent dyes Sytox Green, a membrane impermeant nucleic acid stain (Molecular Probes, Eugene, OR), or fluorescent brightener 28 (Sigma), which stains the $\beta-1,4$ glucans of the cell wall (Springer and Yanofsky 1989), were used in the study at final concentrations of $1 \mathrm{nM}$ and $4 \mu \mathrm{g} / \mathrm{ml}$, respectively. With non-ethanol-treated fungal structures (spores, microconidia, or mycelial fragments), 66-10 (final concentration of $50 \mu \mathrm{g} / \mathrm{ml}$ ) and Sytox were mixed with the respective fungal structures and incubated at $25^{\circ} \mathrm{C}$ for $30 \mathrm{~min}$. In a different regime, 66-10 was first incubated with the fungal structures for $30 \mathrm{~min}$ and then Sytox dye was added without an incubation period. The fungal structures were also incubated with 66-10 in the presence of fluorescent brightener 28 for $30 \mathrm{~min}$ to determine what effect 66-10 would have on cell wall integrity. To obtain compromised membranes under control conditions, the fungal structures were incubated in $70 \%$ ethanol for 10 min at $25^{\circ} \mathrm{C}$ (Springer and Yanofsky 1989) and then washed $2 \times$ in PDB. The fungal structures were then stained with Sytox or exposed to a mixture of Sytox and 66-10 without incubation. The structures were also incubated with 66-10 for 30 min and then stained with Sytox and observed immediately or incubated with 66-10 for $30 \mathrm{~min}$ and stained with Sytox for 30 min before observation. The ethanol-treated fungal structures were also incubated for $30 \mathrm{~min}$ in the presence of fluorescent brightener 28 to observe any effects on cell wall integrity. Other controls consisted of a mixture of each fluorescent dye with each fungal structure from the respective fungal isolates without $66-10$ or ethanol treatment. The stained structures were examined with an Olympus microscope (model BH-2) equipped with an Olympus fluorescent microscopy attachment 
(model BH2-RFC) and an Olympus automatic photomicrographic system (model PM-10ADS) with an Olympus $35 \mathrm{~mm}$ camera (model C-35AD-4) (Olympus, Lake Success, NY). Kodak Ektachrome P1600 film (EPH 135-36) was used to capture the images. A time course study with $C$. fagacearum spores, 66-10, and Sytox was used to resolve the exposure time necessary for the peptide to compromise fungal membranes. A series of microfuge tubes $(1.5 \mathrm{ml})$ were set up to contain $500 \mu \mathrm{l}$ of a $1 \times 10^{6}$ spores per $\mathrm{ml}$ suspension and Sytox $(1 \mathrm{nM})$. The peptide was then added to individual tubes, mixed, and allowed to incubate for time intervals of $0,5,10$, 15 , and $30 \mathrm{~min}$ before being observed by fluorescent microscopy. Each time interval was performed in duplicate in three independent experiments. The ratio of fluorescent spores to nonfluorescent spores was used to determine the percentage of compromised spores present in the observed field. To determine the kill-time for $C$. fagacearum spores with $66-10$, a time course study was performed. Spores $(5 \times$ $\left.10^{6}\right)$ were incubated with $66-10(10 \mu \mathrm{g} / \mathrm{ml})$ in a shaking water bath $\left(25^{\circ} \mathrm{C}\right)$ for time intervals of $0,5,10,15,30,45$, and $60 \mathrm{~min}$. After the respective time intervals had expired, the tubes were removed from the water bath and a dilution plating was performed on PDA. After 4 days at $25^{\circ} \mathrm{C}$, the number of $\mathrm{CFU}$ was obtained. Each time interval exposure and plating was performed in triplicate. The percent difference between the number of CFU for the peptide-treated spore platings and for the control platings was used to calculate the percent kill at each time interval.

\section{Mutagenic potential of bioactive peptides.}

The mutagenic potential of the defined hexapeptide and pentapeptide was evaluated by a Salmonella plate incorporation assay as described by Ames et al. (Ames et al. 1973). Hexapeptide 66-10 and pentapeptide PPD1 were tested at concentrations of 300 to $9.37 \mu \mathrm{g} / \mathrm{ml}$ in a serial dilution series. Two Salmonella typhimurium tester strains (Ames et al. 1973) were used in the assay, TA98 (hisD3052, rfa, $\Delta$ uvrB, pKM101) or TA100 (hisG46, rfa, $\Delta$ uvrB, pKM101). This assay was completed with and without metabolic activation. Metabolic activation was accomplished with Aroclor-1254induced S9 rat liver microsomes (Microbiological Associates, Rockville, MD). Two independent assays were completed for each bacterial test strain. All assays were performed in triplicate at the designated peptide concentrations. Both negative and positive controls were included in all the assays. Dimethyl sulfoxide (DMSO) (Sigma) served as the negative solvent control in all assays. The compounds benzo(a)pyrene $(0.2$ $\mathrm{mg} / \mathrm{ml}$ in DMSO) and 2-nitrofluorene $(0.5 \mathrm{mg} / \mathrm{ml}$ in DMSO) served as positive controls with and without metabolic activation, respectively, for peptide PPD1 testing. The compound 2aminofluorene $(0.5 \mathrm{mg} / \mathrm{ml}$ in DMSO) (Sigma) served as the positive control with and without metabolic activation for 6610 testing. A test was considered positive if the bacterial counts were increased twofold over the negative control at two consecutive doses (Chu et al. 1981).

\section{Hemolytic activity of the defined hexapeptide 66-10.}

The potential hemolytic activity of the defined hexapeptide 66-10 was established with human, bovine, and ovine red blood cells. Each of the respective red blood cells was isolated by centrifugation at $3,024 \times g$ for $5 \mathrm{~min}$ at $5^{\circ} \mathrm{C}$. Following isolation, the cells were washed $3 \times$ in phosphate buffered saline (PBS) $\left(10 \mathrm{mM} \mathrm{Na}_{2} \mathrm{PO}_{4}, 0.9 \% \mathrm{NaCl}, \mathrm{pH}=7.4\right)$ and diluted to a final optical density of 1.200 at $600 \mathrm{~nm}$. The hexapeptide 66-10 (suspended in sterile, distilled, deionized $\mathrm{H}_{2} \mathrm{O}$ ) was diluted in $2 \times$ PBS to obtain a stock suspension of $624 \mu \mathrm{g} / \mathrm{ml}$ in $1 \times$ PDB. Peptide concentrations tested ranged from 312 to $0 \mu \mathrm{g} / \mathrm{ml}$ in repeated twofold dilutions with $0.5-\mathrm{ml}$, sterile, microfuge tubes (final volume of $100 \mu \mathrm{l}$ per tube). Following the dilution series, $100 \mu \mathrm{l}$ of each of the respective red blood cells was added to each tube and the tubes were incubated in a $37^{\circ} \mathrm{C}$ water bath. After $1 \mathrm{~h}$, the tubes were centrifuged $(13,000 \times g)$ for $5 \mathrm{~min}$. The supernatant was removed from the tubes and absorbance readings (at $414 \mathrm{~nm}$ ) were recorded on a Beckman DU-64 spectrophotometer (Beckman Instruments, Fullerton, CA). A $0.1 \%$ solution of the anionic detergent Triton X-100 (Sigma) or a concentration range of mellitin (Sigma) served as the positive (hemolytic) control. The negative (nonhemolytic) control consisted of only PBS and red blood cells. Each of the experiments was performed in duplicate.

\section{Absorption studies.}

To determine if hexapeptide 66-10 inserted reversibly into the fungal membrane, absorption studies were performed with C. fagacearum spores. C. fagacearum spores $\left(1 \times 10^{6}\right.$ spores per $\mathrm{ml})$ were incubated in the presence of $66-10(100 \mu \mathrm{g} / \mathrm{ml})$ at $25^{\circ} \mathrm{C}$. After $1 \mathrm{~h}$, the spores were centrifuged $(13,000 \times g)$ and the supernatant $(50 \mu \mathrm{l})$ was titered against $C$. fagacearum with the protocol for peptide testing as described. The pellet was washed $2 \times$ with $25 \mu \mathrm{l}$ of PDB and the combined supernatant was titered against $C$. fagacearum. Inert, acid-washed glass beads $\left(1 \times 10^{4}\right.$ beads per $\left.\mathrm{ml}\right)($ Sigma; mean diameter 106 $\mu \mathrm{m})$ having a hydrophilic surface, or latex polystyrene beads $\left(6 \times 10^{6}\right.$ beads per $\left.\mathrm{ml}\right)$ (Sigma; mean diameter $\left.3 \mu \mathrm{m}\right)$ having a hydrophobic surface, were also incorporated in place of $C$. fagacearum spores to determine nonspecific binding. Supernatants were assayed as above for activity.

\section{ACKNOWLEDGMENTS}

We thank Dan Ebbole, Clint Magill, and Jordan Fishman for their helpful discussion. This research was supported by the Advanced Technology Program of the Texas Higher Education Coordinating Board and Ceres Technologies, Inc., of San Antonio, TX.

\section{LITURATURE CITED}

Agawa, Y., Lee, S., Ono, S., Aoyagi, H., Ohno, M., Taniguchi, T., Anzai, K., and Kirino, Y. 1991. Interaction with phospholipid bilayers, ion channel formation, and antimicrobial activity of basic amphipathic $\alpha$ helical model peptides of various chain lengths. J. Biol. Chem. 266:20218-20222.

Ames, B. N., Durston, W. E., Yamasaki, E., and Lee, F. D. 1973. Carcinogens are mutagens: A simple test system combining liver homogenates for activation and bacteria for detection. Proc. Natl. Acad. Sci. USA 70:2281-2285.

Anzai, K., Hamasuna, M., Kadono, H., Lee, S., Aoyagi, H., and Kirino, Y. 1991. Formation of ion channels in planer lipid bilayer membranes by synthetic basic peptides. Biochim. Biophys. Acta 1064:256-266.

Ayers, W. A., and Lumsden, R. D. 1975. Factors affecting production and germination of three Pythium species. Phytopathology 65:10941100.

Bessalle, R., Gorea, A., Shalit, I., Metzger, J., Dass, C., Desiderio, D. and Fridkin, M. 1993. Structure-function studies of amphiphilic antibacterial peptides. J. Med. Chem. 36:1203- 1209. 
Bessalle, R., Kapitkovsky, A., Gorea, A., Shalit, I., and Fridkin, M. 1990. All D-magainins: chirality, antimicrobial activity, and proteolytic resistance. FEBS Lett. 274:151-155.

Blondelle, S. E., and Houghten, R. A. 1992. Design of model amphipathic peptides having potent antimicrobial activities. Biochemistry 31 : 12688-12694.

Blondelle, S. E., and Houghten, R. A. 1996. Novel antimicrobial compounds identified using synthetic combinatorial library technology. Trends Biotechnol. 14:60-65.

Blondelle, S. E., Takahashi, E., Dinh, K. T., and Houghten, R. A. 1995. The antimicrobial activity of hexapeptides derived from synthetic combinatorial libraries. J. App. Bacteriol. 78:39-46.

Blondelle, S. E., Takahashi, E., Weber, P. A., and Houghten, R. A. 1994. Identification of antimicrobial peptides by using combinatorial libraries made up of unnatural amino acids. Antimicrob. Agents Chemother. 38:2280-2286.

Bowman, H. G., Faye, I., Gudmundsun, G. H., Lee, J.-Y., and Lidholm, D.-A. 1991. Cell-free immunity in Cecropia. Eur. J. Biochem. 201:2331.

Chikindas, M. L., Garcia-Garcera, M. J., Driessen, A. J. M., Ledeboer, A. T., Nissen-Meyer, J., Nes, I. F., Abee, T., Konings, W. N., and Venema, G. 1993. Pediocin PA-1, a bacteriocin from Pediococcus acidilactici PAC1.0, forms hydrophilic pores in the cytoplasmic membrane of target cells. Appl. Environ. Microbiol. 59:3577-3584.

Chu, K. C., Patel, K. M., Lin, A. H., Tarone, R. E., Linhart, M. S., and Dunkel, V. C. 1981. Evaluation statistical analyses and reproducibility of microbial mutagenicity assays. Mutation. Res. 85:119-132.

Esposito, R., and Fletcher, A. M. 1961. The relationship of pteridine biosynthesis to the action of copper 8-hydroxy- quiolate on fungal spores. Arch. Biochem. Biophys. 93:369-376.

Evans, E. W., and Harmon, B. G. 1995. A review of antimicrobial peptides: Defensins and related cationic peptides. Vet. Clin. Pathol. 24: 109-116.

Ganz, T., and Lehrer, R. T. 1995. Defensins. Pharmacol. Ther. 66:191205.

Hancock, J. G. 1993. Fungal rootlet colonization and forage yields of alfalfa in fungicide-treated field plots. Plant Dis. 77:601-608.

Hansen, J. N. 1993. Antibiotics synthesized by posttranscriptional modification. Annu. Rev. Microbiol. 47:535-564.

Hightower, R., Baden, C., Penzes, E., and Dunsmuir, P. 1994. The expression of cecropin peptide in transgenic tobacco does not confer resistance to Pseudomonas syringae pv tabaci. Plant Cell Rep. 13:295299.

Houghten, R. A., Appel, J. R., Blondelle, S. E., Cuervo, J. H., Dooley, C. T., and Pinilla, C. 1992. The use of synthetic peptide combinatorial libraries for the identification of bioactive peptides. BioTechniques 13:412-421.

Houghten, R. A., Dinh, K. T., Burcin, D. E., and Blondelle, S. E. 1993. The systematic development of peptides having potent antimicrobial activity against $E$. coli through the use of synthetic peptide combinatorial libraries. Pages 249-256 in: Techniques in Protein Chemistry,
IV; Sixth Protein Society Symposium. R. H. Angeletti, ed. Academic Press, San Diego, CA.

Jawetz, E., Melnick, J. L., and Adelberg, E. A. 1982. Antimicrobial chemotherapy. Pages 117-145 in: Review of Medical Microbiology. 15th ed. Lange Medical Pub., Los Altos, CA.

Kerwin, J. L., and Duddles, N. D. 1989. Reassessment of the role of phospholipids in sexual reproduction by sterol-auxotrophic fungi. J. Bacteriol. 171:3831-3839.

Lear, J. P., Wasserman, Z. R., and Degrado, W. F. 1988. Synthetic, amphiphilic peptide models for protein ion channels. Science 246:11771181.

Maloy, W. L., and Kari, U. P. 1995. Structure-activity studies on magainins and other host defense peptides. Biopolymers (Peptide Science) 37:105-22.

Marcos, J. F., Beachy, R. N., Houghten, R. A., Blondelle, S. E., and Perez-Paya, E. 1995. Inhibition of a plant virus infection by analogs of melittin. Proc. Natl. Acad. Sci. USA 92:12466-12469.

McGinnis, M. R., and Rinaldi, M. G. 1991. Antifungal drugs: Mechanisms of action, drug resistance, susceptibility testing, and assays of activity in biological fluids. Pages 198-257 in: Antibiotics in Laboratory Medicine. 3rd ed. V. Lorian, M.D., ed. Williams and Wilkins, Baltimore, MD.

Merrifield, R. B., Merrifield, E. L., Juvvadi, P., Andreu, D., and Boman, H. G. 1994. Design and synthesis of antimicrobial peptides. Pages 526 in: Ciba Foundation Symposium, No. 186. Antimicrobial Peptides Symposium. H. G. Bowman, J. Marsh, and J. A. Goode, eds. John Wiley and Sons, Chichester, England.

Olsen, R. H., and Hansen, J. 1976. Evolution and utility of a Pseudomonas aeruginosa drug resistance factor. J. Bacteriol. 125:837-844.

Pinto, F., Pedregosa, A. M., Monistrol, I. F., and Laborda, F. 1993. Effects of antimicrotubular fungicides on conidiation in Aspergillus nidulans. Rev. Iberoam. Micol. 10:100-104.

Powell, W. A., Catranis, C. M., and Maynard, C. A. 1995. Synthetic antimicrobial peptide design. Mol. Plant-Microbe Interact. 8:792794

Qu, X., Steiner, H., Engstrom, A., Bennich, H., and Boman, H. G. 1982. Insect immunity: Isolation and structure of cecropins $\mathrm{B}$ and $\mathrm{D}$ from pupae of the Chinese oak silk moth, Antheraea pernyi. Eur. J. Biochem. 127:219-224.

Rao, A. G. 1995. Antimicrobial peptides. Mol. Plant-Microbe Interact. 8:6-13.

Springer, M. L., and Yanofsky, C. 1989. A morphological and genetic analysis of conidiophore development in Neurospora crassa. Genes Dev. 3:559-571.

Williams, R. J., and Ayanaba, A. 1975. Increased incidence of Pythium stem rot in cowpeas treated with benomyl and related fungicides. Phytopathology 65:217-218.

Zasloff, M. 1987. Magainins, a class of antimicrobial peptides from Xenopus skin: Isolation, characterization of two active forms, and partial cDNA sequence of a precursor. Proc. Natl. Acad. Sci. USA 84:5449-5453. 